\title{
Estimation of Depth to Bouguer Anomaly Sources Using Euler Deconvolution Techniques
}

\author{
Ocena globine do virov Bouguerjeve anomalije $\mathrm{z}$ \\ uporabo Eulerjevih dekonvolucijskih tehnik
}

\author{
Gideon Oluyinka Layade ${ }^{1, *}$, Hazeez Edunjobi ${ }^{1}$, Victor Makinde', Babatunde Bada² \\ 'Department of Physics, Federal University of Agriculture, Abeokuta \\ ${ }^{2}$ Department of Environmental Management \& Toxicology, Federal University of Agriculture, Abeokuta \\ *Layadeoluyinka018@gmail.com
}

\begin{abstract}
The geophysical measurement of variations in gravitational field of the Earth for a particular location is carried out through a gravity survey method. These variations termed anomalies can help investigate the subsurface of interest. An investigation was carried out using the airborne satellite-based (EGM08) gravity dataset to reveal the geological information inherent in a location. Qualitative analysis of the gravity dataset by filtering techniques of two-dimensional fast Fourier transform (FFT2D) shows that the area is made up of basement and sedimentary Formations. Further enhancements on the residual anomaly after separation show the sedimentary intrusion into the study area and zones of possible rock minerals of high and low density contrasts. Quantitative interpretations of the study area by 3-D Euler deconvolution depth estimation technique described the depth and locations of gravity bodies that yielded the gravity field. The result of the depth to basement approach was found to be in the depth range of $930 \mathrm{~m}$ to 2,686 $\mathrm{m}$ (for Structural Index, SI = 0). The research location is a probable area for economic mineral deposits and hydrocarbon exploration.
\end{abstract}

Key words: gravitational field, intrusion, enhancements, anomalous sources, density contrasts

\section{Povzetek}

Izvedene so bile geofizikalne meritve sprememb zemeljskega gravitacijskega polja na določenih lokacijah. Spremembe gravitacijskega polja, imenovane anomalije, so lahko $\mathrm{v}$ pomoč pri raziskovanju določenega podzemnega območja. V raziskavi so bili za obravnavano območje uporabljeni podatki gravitacijskega zemeljskega modela (EGM08). Kvalitativna analiza gravitacijskih podatkov s filtracijskimi tehnikami dvodimenzionalne hitre Fourierjeve transformacije (FFT2D) prikazuje, da območje sestavljajo kamnine podlage in sedimentne formacije. Nadaljnje analize prikazujejo sedimentne intruzije v obravnavano območje in območja potencialnih kamninskih mineralov z visokim in nizkim kontrastom gostote. Kvantitativna interpretacija obravnavanega območja $s$ tehniko 3D Eulerjeve dekonvolucije razkriva globino in lokacijo gravitacijskih teles, ki vplivajo na spremembo gravitacijskega polja. Rezultat analize je globina do kamninske podlage, ki se nahaja v območju od 930 m do 2,686 m (za strukturni indeks SI $=0$ ). Raziskovana lokacija je potencialno območje za ekonomično pridobivanje mineralnih surovin in raziskovanje ogljikovodikov.

Ključne besede: gravitacijsko polje, intruzija, izboljšave, viri anomalij, kontrast gostote 


\section{Introduction}

The inherent physical properties of subsurface media such as sediments, rocks, voids, water, contacts among others are examined through geophysical survey [1]. Among these geophysical surveys is the gravity method which is primarily concerned with measuring gravitational field as part of potential field measurement [2-3]. It tries to determine the nature of the subsurface by relating the measured gravitational fields to density contrasts. Gravity survey can be carried out on the ground and can also be airborne but the airborne survey helps to cover areas that cannot be easily accessible, e.g. on waters [4]. Previous works in the locality have used magnetic method and rock petrography to investigate the study area. A number of techniques can be employed to yield the near surface spread of parameters describing the variations which include the 3-D analytic signal technique [5], Werner deconvolution, [6], 3-D Euler deconvolution, [7] and Multiple Source Werner deconvolution [8].

Qualitatively, the gravity data is interpreted in order to describe and explain some important features which the results of the survey exposed with respect to possible geological formations and structures yielding the anomalies [9]. While the quantitative interpretations involve numerical estimation of the depths and dimensions of anomalous sources. The research is thus, to estimate depths to gravity sources in the area of Abeokuta and environ using Bouguer gravity data. Hence, the application of 3-D Euler deconvolution technique for computing the burial depths of anomalies.

In 1867, Sir Isaac Newton proposed two laws upon which the gravity method is based: the law of universal gravitation that describes the force of attraction between two separate bodies of known masses [10-11] and the law of motion, which relates the applied force to the rate of change of momentum of a body.

Mathematically:

$$
F=\frac{G M m}{R^{2}}
$$

Where:

$F=$ force of attraction between two separate bodies

$\mathrm{G}=$ constant of gravitation $\left(\mathrm{G}=6.67 \times 10^{-11} \mathrm{Nm}^{2} / \mathrm{kg}^{2}\right)$

$M=$ mass of the earth

$m=$ mass of the second body

$R$ = separating distance

Also, the second law of motion can be expressed

as:

$F=\frac{d p}{d t}$

Thus:

$F=\frac{d(m v)}{d t}=m g$

Where:

$F=$ the applied force of attraction

$d p=$ momentum change

$d t=$ time difference

Equations (1) and (3) give:

$g=G \frac{M}{R^{2}}$

Equation (4) is the gravitational field of the Earth on any mass.

\section{Description and Geologic Setting of the study area.}

The location of the study area is represented by Figure 1 within latitude $\left(7^{\circ} .00^{1}-7^{\circ} .30\right)$ $\mathrm{N}$ and longitude $\left(3^{\circ} .00^{1}-3^{\circ} .30\right)$ E spanning $3,025 \mathrm{~km}^{2}$ area. Basement complex (Abeokuta formation) and sedimentary (Ewekoro formation) respectively are the predominant geological nature of the area [12]. While the older granites which are magmatic in nature are of Precambarian age to early Palaeozoic [13]. Gneiss-migmatite complex comprising of gneisses, calcsilicate, quartzite, amphibolites and biotite-hornblende schist is the most 


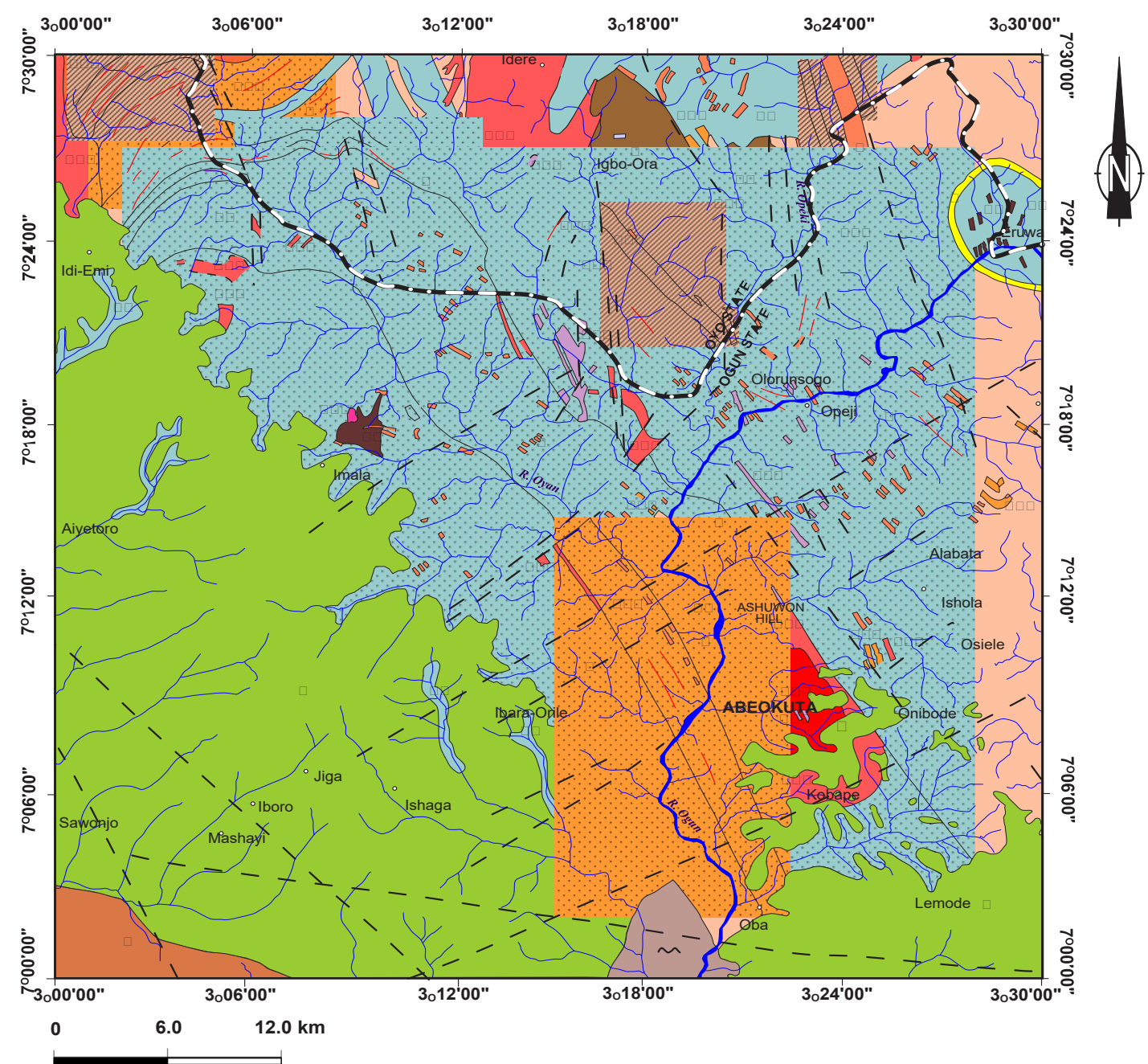

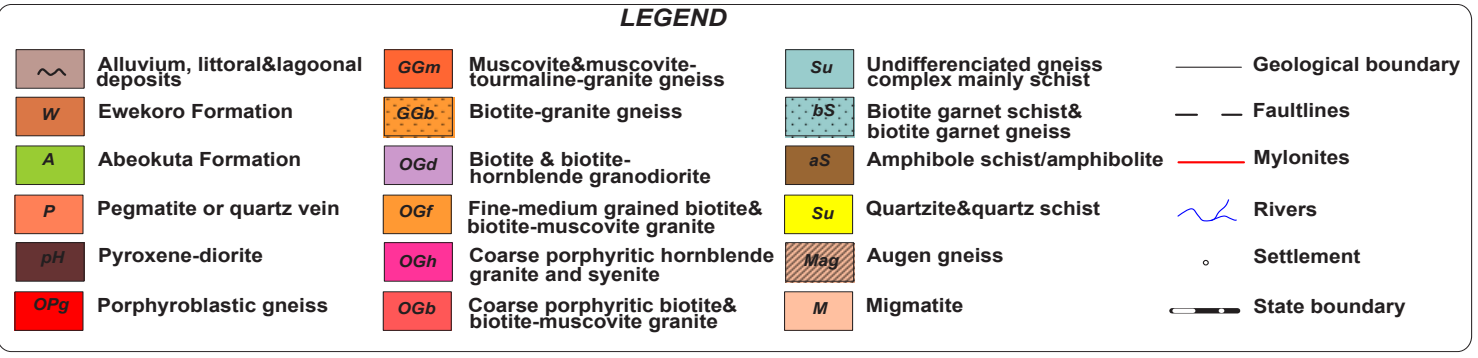

Figure 1: Geological Map of the Study Area.

widely spread rock formation in the area according to Rahaman [14].

\section{Methodology}

The acquired gravity dataset of the study area through Bureau Gravimetrique Internationale (BGI) was processed to produce the Bouguer anomaly map (Figure 2) after being reprojected from the Universal Transverse Mercator of Zone 32 Northing (UTM 32N) to that of UTM 31N. A two-dimensional fast Fourier transform (FFT2D) filter named Magmap, which is an extension of Oasis Montaj (version 8.4) was applied on the Bouguer anomaly map to produce the Radially Average Power Spectrum (RAPS), presented as Figure 4. The spectrum 


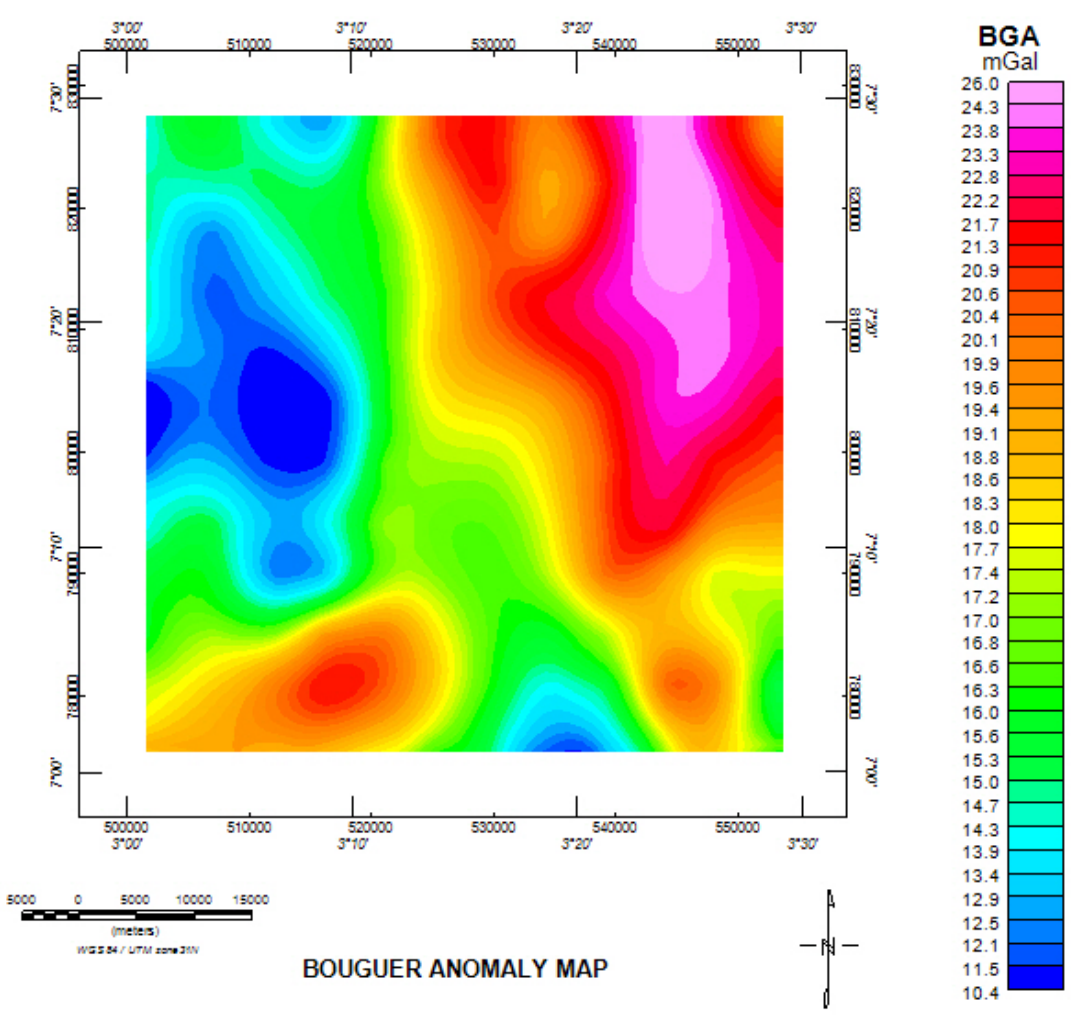

Figure 2: Bouguer Gravity Field of Abeokuta.

aided the visualisation of the three demarcation of deep, intermediate and shallow anomalous gravity sources. Each of the segment is a representative of the gravity responses at given depths. Depth is proportional to the slope of the line segment [15-16]. This research requires a Regional-Residual separation technique to enhance shallower signals. A High-pass filter was employed to obtain the residual anomaly map (Figure 5). Subsequently, residual anomaly map was produced from the Bouguer gravity field $[1,17]$ by setting the cut-off wavenumber at 0.02 cycles $/ \mathrm{km}$ to process the intermediate and shallow sources as the residual anomaly. The resulting residual anomaly was thereafter processed to produce the derivative of the field along the X-direction (Figure 6) and the Analytic signal map, the Analytic signal map (Figure 7) was observed to be a bit noisy and hence, upward continued at $1 \mathrm{~km}$ in order to sharpen the edges of anomalous sources and geological boundaries. These were also achieved through a two-dimensional fast Fourier transform (FFT2D), to accentuate structures linked with near surface causes [18].
The standard 3D Euler-deconvolution method is based on homogeneity equations that relate the gradients' components of the potential field to the source location. The structural index (SI), $\eta$ having values ranging from $0-2$ for gravity sources [19]. These sources are described by different theoretical geometries with corresponding SI as follows; Sphere - ( $\eta$ $=2)$, Vertical line end (pipe) - $(\eta=1)$, Horizontal line (cylinder) - $(\eta=1)$, Thin bed fault - $(\eta=1)$, and Thin sheet edge - $(\eta=0)$ respectively [20]. The 3D Standard Euler equation for potential field according to [20-21] is defined as:

$$
\begin{aligned}
& x \frac{\partial T}{\partial x}+y \frac{\partial T}{\partial y}+z \frac{\partial T}{\partial z}+\eta T=x_{0} \frac{\partial T}{\partial x}+y_{0} \frac{\partial T}{\partial y}+ \\
& z_{0} \frac{\partial T}{\partial z}+\eta b
\end{aligned}
$$

The coordinates of the measuring point are $\mathrm{x}$, $\mathrm{y}$, and $\mathrm{z}$; $\mathrm{b}$ is a base level; the coordinates of the source location are $\mathrm{x}_{0}, \mathrm{y}_{0}$, and $\mathrm{z}_{0}$; while $\mathrm{T}$ is the total potential field respectively. 


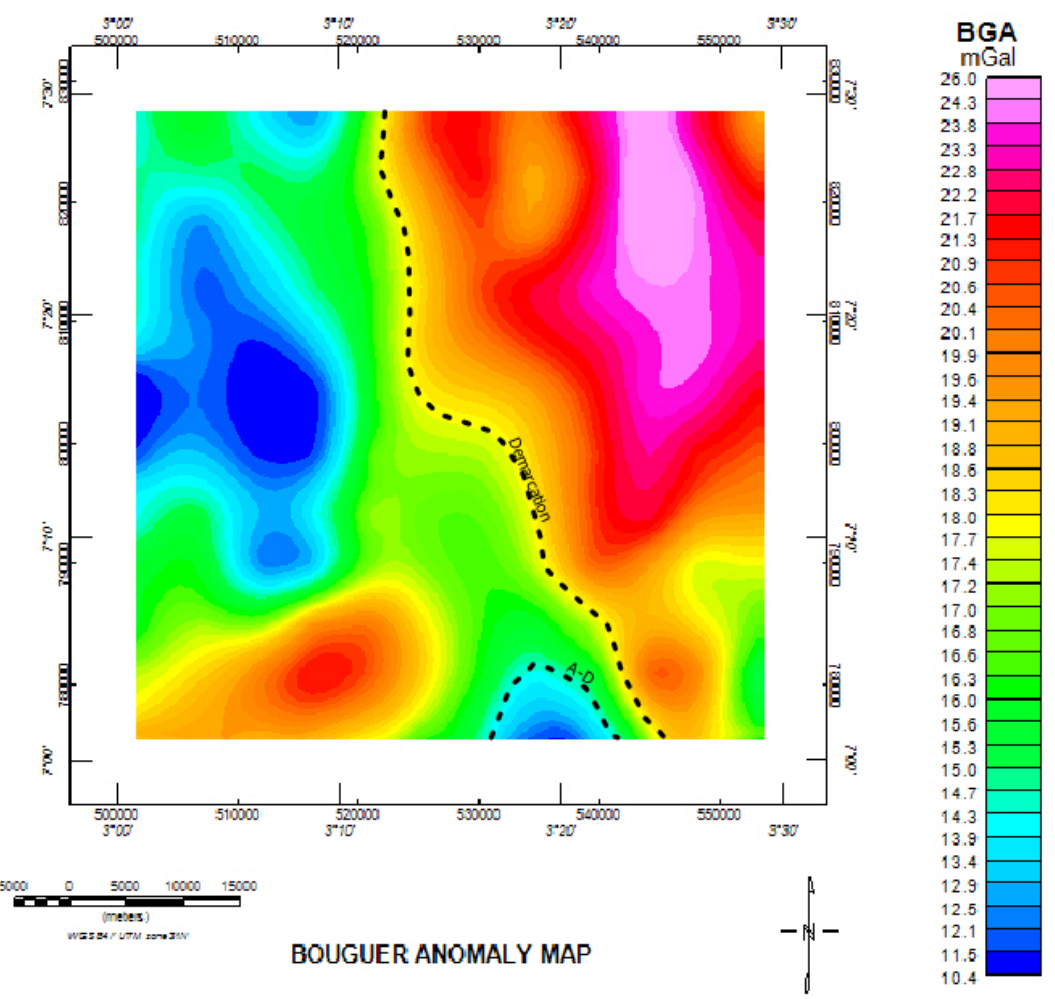

Figure 3: Bouguer Anomaly Map showing some geological features.

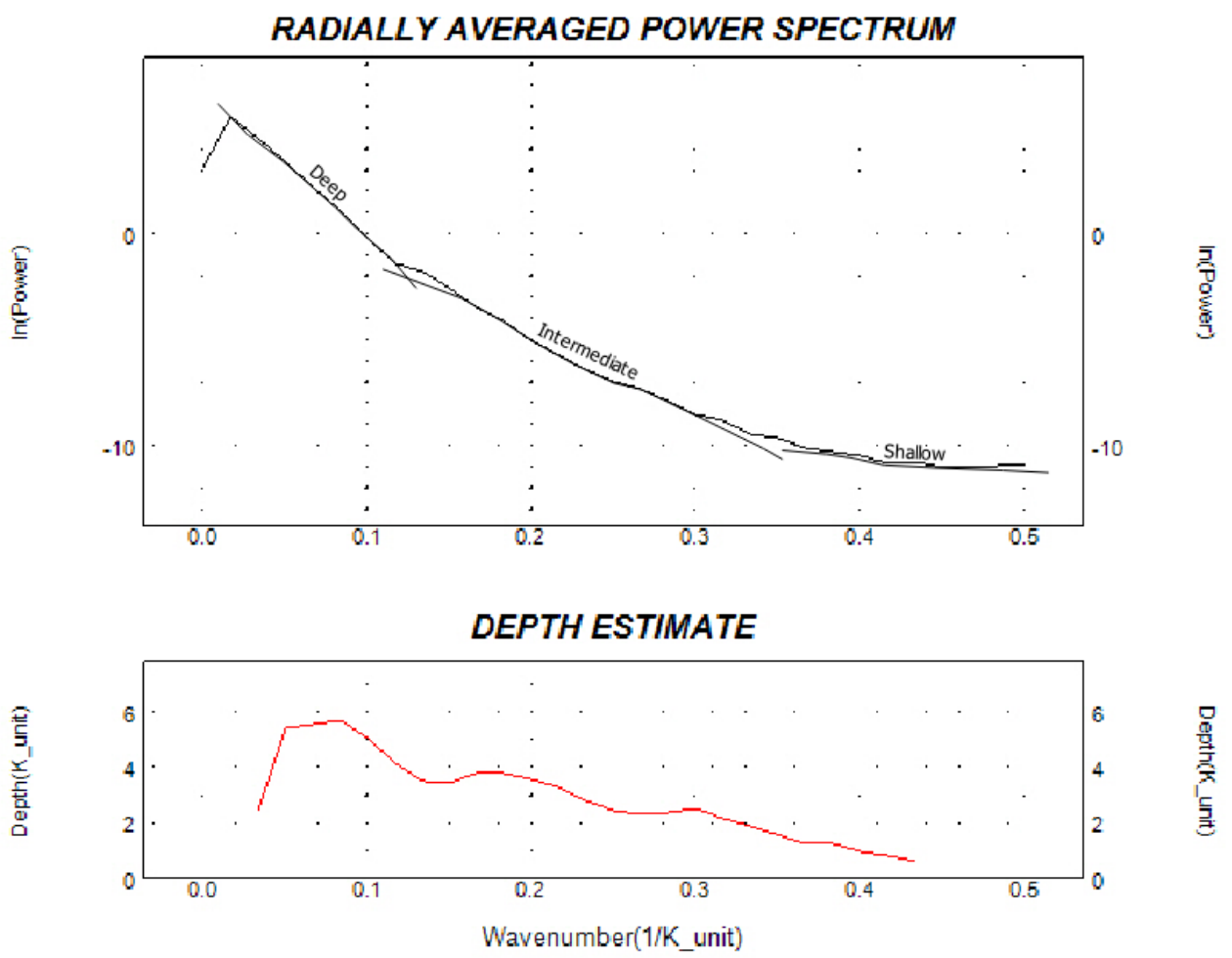

Figure 4: Radially Averaged Power Spectrum of the Gravity Field. 


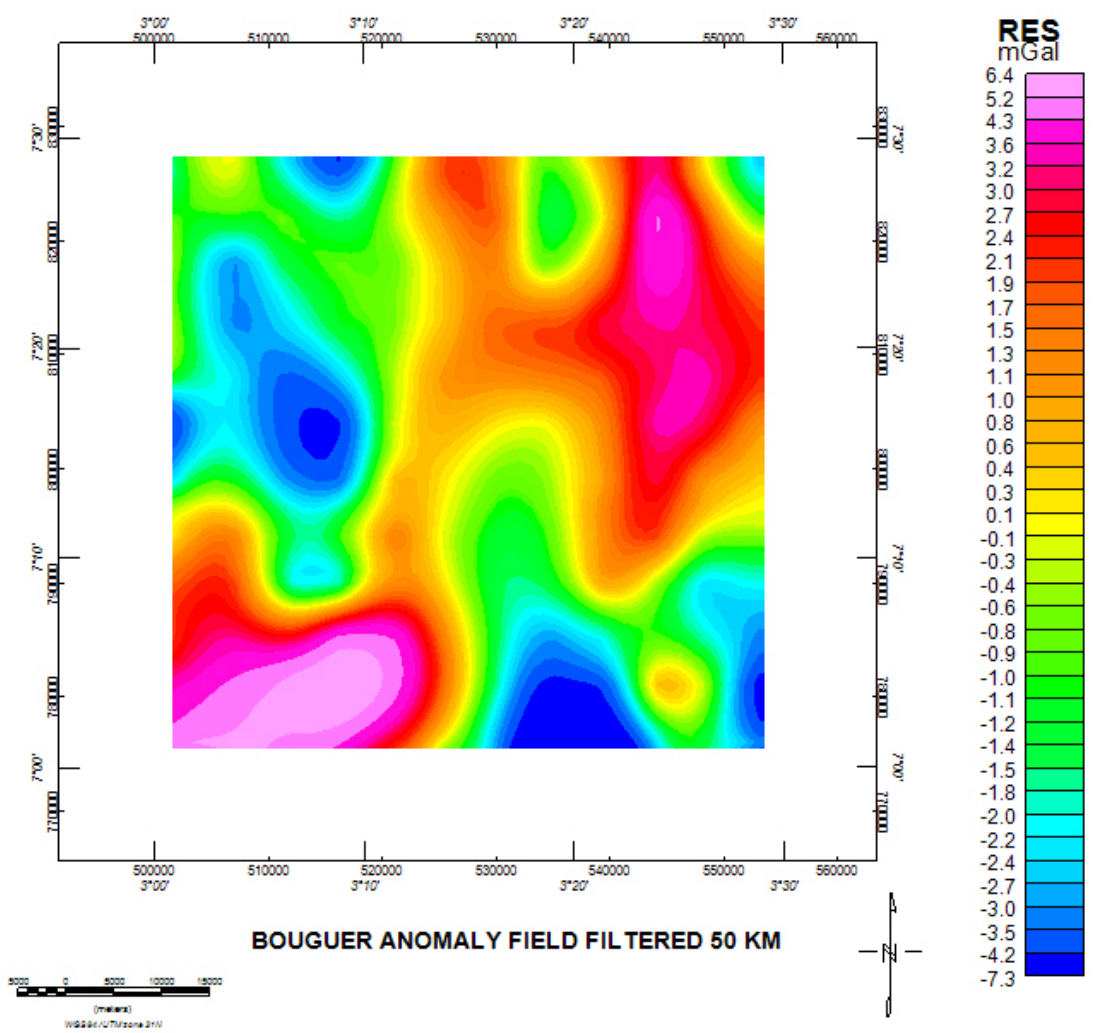

Figure 5: Residual Anomaly Field (Bouguer Gravity Field High-Pass filtered at 50 km).

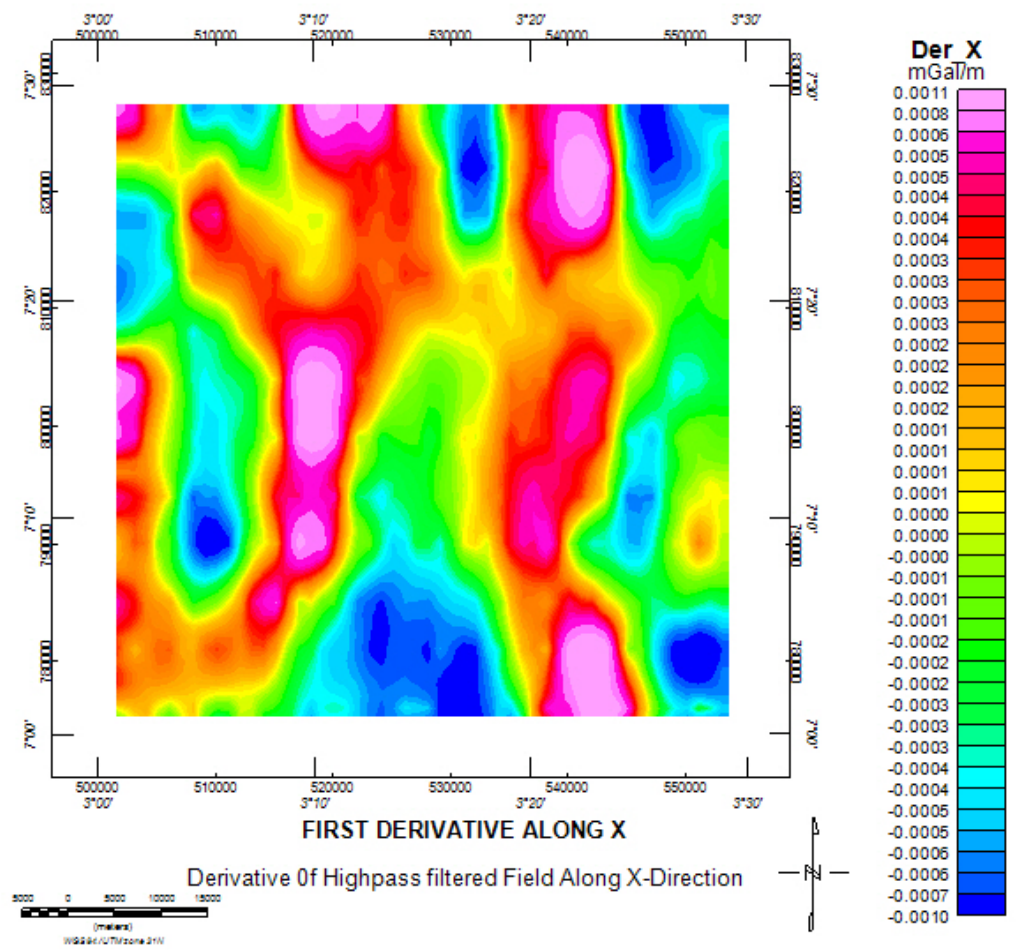

Figure 6: First Horizontal Derivative along X-Direction. 


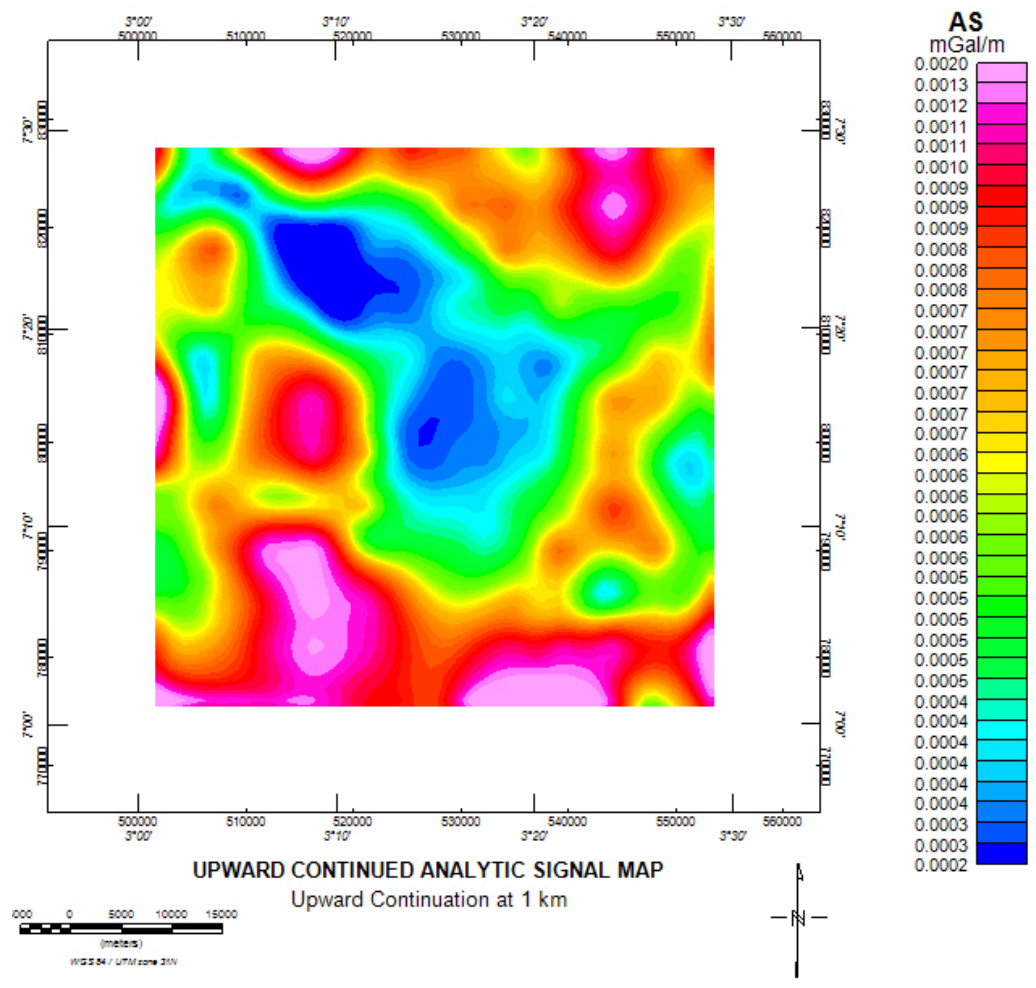

Figure 7: Upward Continued Analytic Signal Map.

In computing the standard Euler deconvolution solutions, the recommendations from the findings of [20] were adopted by using the different structural indices of 0,1 and 2 were tried in solving the solutions but only SI equals 1 gave a geologically meaningful solution, which reveals that the area is possibly characterized by structures like faults, contacts and thin sheet edge (dike), [22]. A square window size of 3000 by $3000 \mathrm{~m}$ containing number of grid cells in the gridded dataset was used in order to accommodate the depth of sources, as investigated by previous researches in the study area.

\section{Results and Discussions}

\section{Qualitative Treatment}

The digitized data set of the area produced the Bouguer gravity map in Figure 2 and the radially average power spectrum in Figure 3 . The anomaly was filtered to describe features associated with intermediate and shorter wavelengths. While Figure 5 shows the residual map for the separated Bouguer anomaly grid. Subsequently, the derivative maps of the field were generated from the high-pass filtered gravity filed, one of which is the derivative along $\mathrm{X}$ - direction presented as Figure 6 and the Analytic signal map that Figure 7 represents.

In Figure 2, a gravity value ranging from 10.40 $\mathrm{mGal}$ to $26.40 \mathrm{mGal}$ is observed on the Bouguer anomaly field. The anomaly map reveals high gravimetric values, towards northeastern zone of the area, which conforms to the lithological differences in the subsurface. On the other hand, within the southern, southwestern and northwestern regions, the variations in the lithology of the intra-basement of the area recorded low gravimetric values. Furthermore, the dominance of high gravity values around the Northeastern portion is a representative of possible undifferentiated gneiss complex which is mainly schist around 'Eruwa' (when compared with the Geological map of the study area). The portion marked 'A-D' on Figure 3 are alluvial and lagoonal deposits at the Oba area and the 'demarcated' marked region which is the transition zone that divides the 

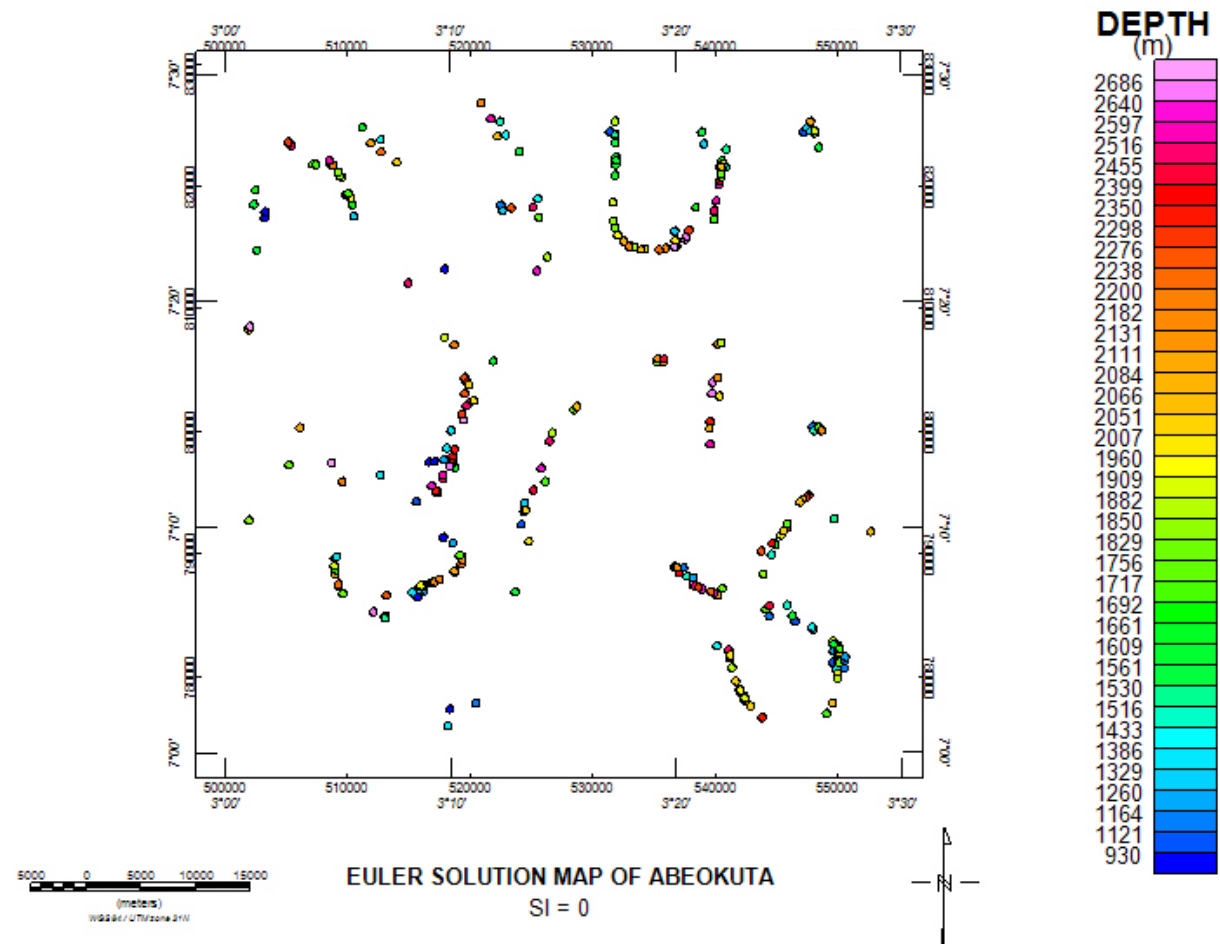

Figure 8: Euler Solution Map of Abeokuta, for the Structural Index $S I=0$.

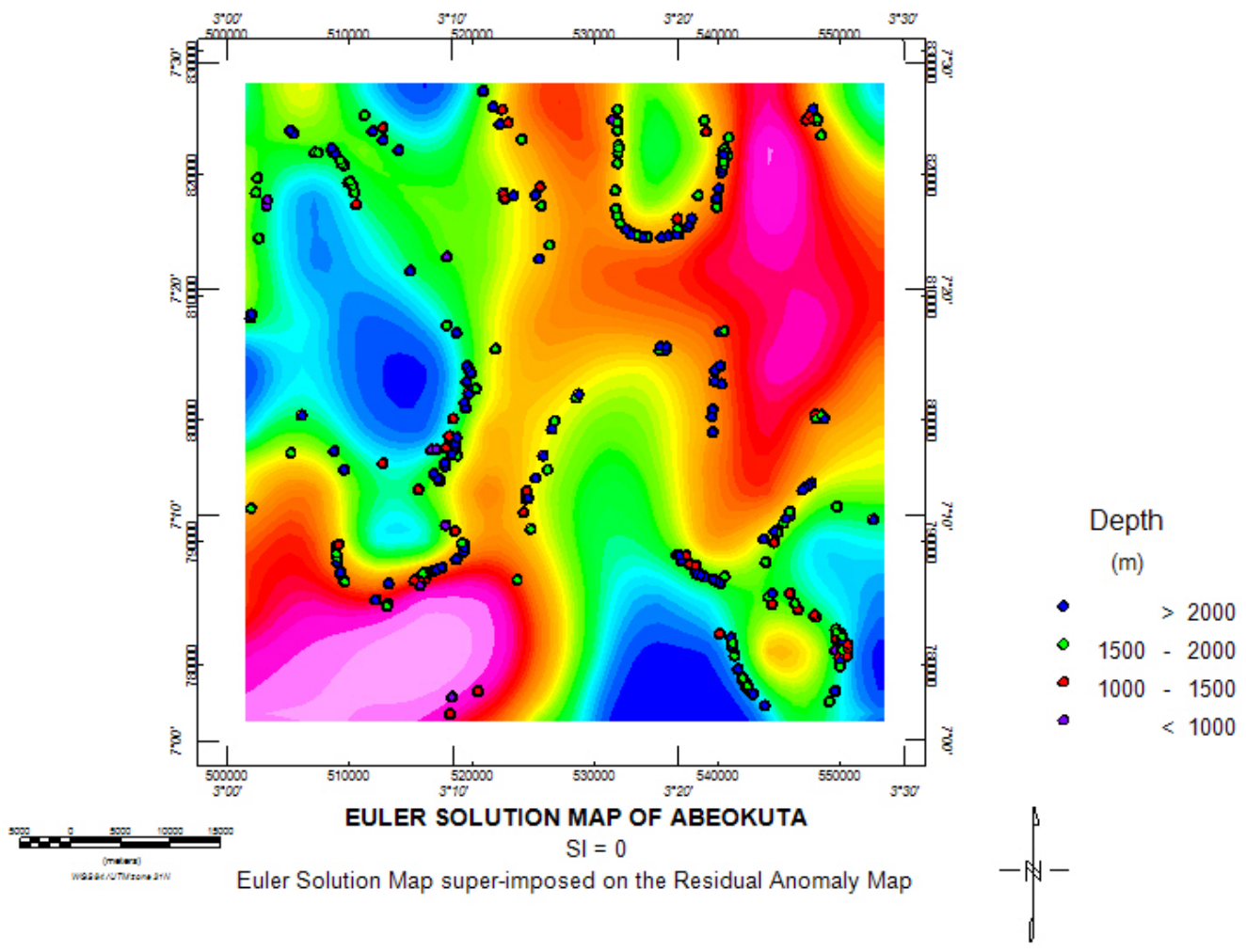

Figure 9: Euler Solution Map superimpose on the Residual Anomaly Map. 


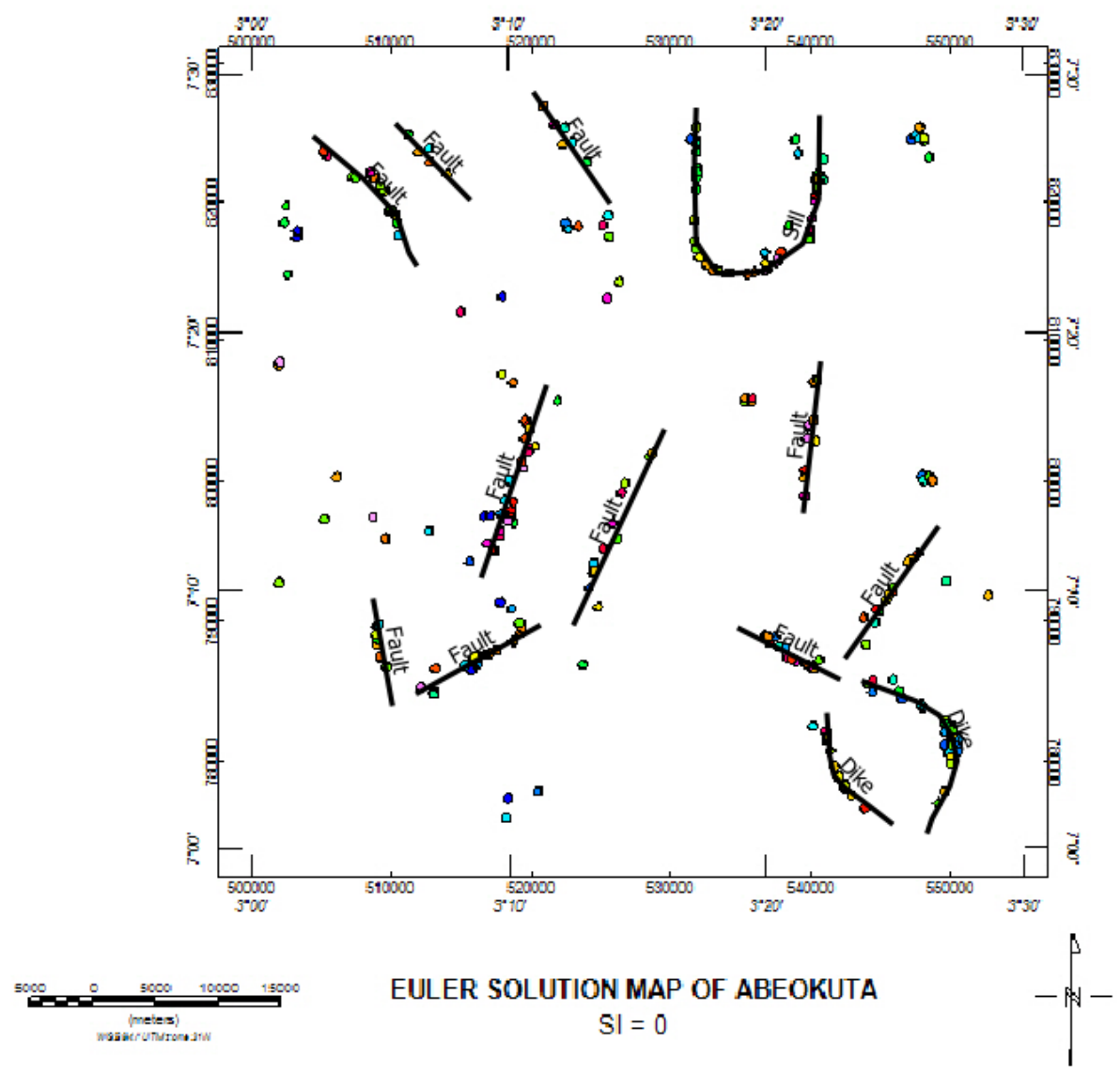

Figure 10: Lineament Map of the Study Area, inferred on the Euler Solution Map.

study location into two distinctive geological Formations of Basement and Sedimentary Formations.

The residual anomaly map in Figure 5 (Gravity field filtered at $50 \mathrm{~km}$ ) has intermediate and short wavelengths with values ranging from -7.3 $\mathrm{mGal}$ to $6.4 \mathrm{mGal}$. In the southern and northern zones, gravity values are high but varies in Northwestern and Southeastern regions. In parts of the study area, there are sedimentary intrusions into the northern zones with low gravity values, other low-density areas suggest possible sedimentation (like Araromi and Abeokuta Formations).

High pass-filtered residual anomaly grid gave rise to the derivative grids contained in Figures 6 and 7 to enhance the visualization and localization of the anomalous sources. The anomalies of the first horizontal derivative along the X-direction are aligned along N-S trend laterally, the anomalies or structures that trend in the same direction are from the same tectonic event, as posited by [23], while the regional effects of the total field have been attenuated. The range of anomaly for the Analytic Signal in Figure 7 is $0.002 \mathrm{mGal}$ to $0.02 \mathrm{mGal}$ with high gravity responses spatially distributed all over the area.

\section{Depth Estimation and Structural Evaluation}

The Figure 8 shows the Euler map with SI equals 0 having maximum range of 2,350 $\mathrm{m}$ to $2,686 \mathrm{~m}$ and average of 2,518 $\mathrm{m}$ (deep sources); and a minimum range of $930 \mathrm{~m}$ to $1,260 \mathrm{~m}$ with an average minimum depth of 1,095 $\mathrm{m}$ (shallow sources).

The depth to basement of gravity anomalous sources evaluated in this research is a true representation of the sedimentary thickness, the works of [24] and [25] in and around the study area are all in agreement with the results of this research. The depth range obtained 
can slightly hold prospect for hydrocarbon accumulation as posited by [26] that the minimum sedimentary thickness required for hydrocarbon exploration is $2,300 \mathrm{~m}$.

Figure 10 represents the lineament map of inferred structures on the Euler depth solution map. The elongation of continuous plotted solutions confirms the presence of geological structures like faults, dike and/or sill in the area of investigation.

\section{Conclusion}

The qualitative interpretation of the area by the filtering techniques reveal the distinct features of basement and sedimentary Formations of the area. Alluvial deposits zone, sedimentary intrusions into the area and regions of possible high and low-density rock minerals have been mapped.

Conclusively, the depths to basement of gravity sources in the area show prospects for hydrocarbon exploration and holds high potential for economic minerals exploration.

\section{References}

[1] Reynolds, M.J. (1997): Introduction to applied and environmental geophysics. John Wiley and Sons: New York, USA, $796 \mathrm{p}$.

[2] Mickus, K., Hinojosa, J. (2002): The complete gravity gradient tensor derived from vertical gravity data: A Fourier Transform technique. Journal of Applied Geophysics, 46, 159-174.

[3] Nicolas, O.M. (2009): The Gravity Method. Exploration for Geothermal Resources, pp. 1-9.

[4] Telford, W.M., Geldart, L.P., Sheriff, R.E. (1990): Applied geophysics (2nd edition), Cambridge University Press: Cambridge, 770 p.

[5] Roest, W.R., Verhoef, J., Pilkington, M. (1992): Magnetic interpretation using 3-D analytic signal. Geophysics, 57, 116-125.

[6] Hartman, R.R., Tesky, D.J., Friedberg, J.L. (1971): A system for rapid digital aeromagnetic interpretation. Geophysics, 36, pp. 891-918.

[7] Reid, A.B., Allsop, J.M., Granser, H., Millett, A.J., Somerton, I.W. (1990): Magnetic interpretation in three dimensions using Euler deconvolution. Geophysics, 55, pp. 80-99.
[8] Hansen, R.O., Simmonds, M. (1993): Multiple-source Werner deconvolution. Geophysics, 58, pp. 17921800.

[9] Revees, C. (2005): Aeromagnetic Surveys; Principles, Practice and Interpretation. GEOSOFT, $155 \mathrm{p}$.

[10] Telford, W.M., Geldart, L.P., Sheriff, R.E., Keys, D.A. (1976): Applied Geophysics. Cambridge University Press, 860p.

[11] Rivas, J. (2009): Gravity and Magnetic Methods. Short course on Surface Exploration for Geothermal Resources. United Nations University, LaGeo: Elsavador, pp. 1-13.

[12] Obaje, N.G. (2009): Geology and mineral resources of Nigeria. Lecture Note in Earth Science Series, 120.

[13] Jones, H.A., Hockey, R.O. (1964): The Geology of Parts of Southwestern Nigeria. Bulletin of Geological Survey of Nigeria, 31, pp. 101-102.

[14] Rahaman, M.A. (1976): Review of the basement geology of south western Nigeria in Geology of Nigeria. Elizabethan publishing company: Lagos, pp. 41-58.

[15] Naidu, P.S. (1968): Spectrum of Potential Field due to randomly distributed sources. Geophysics, 33, pp. 337-345.

[16] Spector, A., Grant, F.E. (1970): Statistical models for interpreting aeromagnetic data. Geophysics, 35, pp. 293-302.

[17] Layade, G.O., Adebo, B.A., Olurin, O.T., Ganiyu, O.M. (2015): Separation of Regional-Residual Anomaly Using Least Square Polynomial Fitting Method. Journal of the Nigerian Association of Mathematical Physics, 30, pp. 69-180.

[18] Hesham, S.Z., Hesham, T.O. (2016): Application of High-Pass Filtering Techniques on Gravity and Magnetic Data of the Eastern Qattara Depression Area, Western Desert, Egypt. National Research Institute of Astronomy and Geophysics, 5, pp. 106-123.

[19] Thompson, D.T. (1982): A new technique for making computer-assisted depth estimates from magnetic data. Geophysics, 47(1), pp. 31-37.

[20] Reid, A.B., Allsop, J.M., Thurston, J.B. (2014): The structural index in gravity and magnetic Interpretation: Errors, uses and abuses. Geophysics, 79(4), pp. 61-66.

[21] Adegoke, J.A., Layade, G.O. (2019): Comparative depth estimation of iron-ore deposit using the DataCoordinate Interpolation Technique for airborne and ground magnetic survey variation. African Journal of Science, Technology, Innovation and Development (AJSTID). 11(5), pp. 663-669, DOI:10.1080/2042133 8.2019.1572702. 
[22] Reid, A.B., Ebbing, J., Webb, S.J. (2014): Avoidable Euler Errors - the use and abuse of Euler deconvolution applied to Potential fields. European Association of Geoscientists \& Engineers, Geophysical Prospecting, 62(5).

[23] Omosanya, K.O., Akinbodewa, A.E., Mosuro, G.O. (2012): Integrated Mapping of Lineaments in AgoIwoye SE, SW Nigeria, Intl. J. Sci. Technol., 1(2), pp. 68-79.

[24] Olowofela, J.A., Akinyemi, O.D., Badmus, B.S., Awoyemi, M.O., Olurin, O.T., Ganiyu, S.A. (2013): Depth estimation and source location of Magnetic anomalies from a Basement Complex Formation, using Local Wavenumber Method (LWM). IOSR Journal of Applied Physics, 4(2), pp. 33-38.

[25] Olurin, O.T., Olowofela, J.A., Akinyemi, O.D., Badmus, B.S., Idowu, O.A., Ganiyu, S.A. (2015): Enhancement and Basement Depth Estimation from Airborne Magnetic Data. African Review of Physics, 10(38), pp. 303-313.

[26] Wright, J.B., Hastings, D., Jones, W.B., Williams, H.R. (1985): Geology and Mineral resources of West Africa. George Allen and Unwin: London, 187 p. 